Japan. J. Med. Sci. Biol., 34, 181-190, 1981

Epidemiological Report

\title{
HEPATITIS B ANTIGEN AND ANTIBODY PREVALENCE OF JAPANESE SERA SELECTED FROM THE 1972 YEAR'S COLLECTION AT NATIONAL SERUM BANK, NATIONAL INSTITUTE OF HEALTH OF JAPAN
}

\author{
Tazuko YUASA, Isamu TAGAYA, Teruaki SEKINE* \\ and KusuYA NISHIOKA** \\ Department of Enteroviruses, National Institute of Health, 7-1, Gakuen 4-chome, \\ Musashimurayama, Tokyo 190-12, *Virology Division, National Cancer \\ Research Institute, Tsukiji 5-chome, Chuo-ku, Tokyo 104, \\ and **Tokyo Metropolitan Institute of Medical Science, \\ 18-22, Honkomagome 3-chome, Bunkyo-ku, Tokyo 113
}

(Received December 16, 1980. Accepted April 27, 1981)

Since Blumberg et al. (1967) reported that apparently healthy carriers of hepatitis $B(\mathrm{HB})$ virus were the important source of infection with this virus, many reports on the prevalence of $\mathrm{HB}$ antigen in healthy populations have appeared (Blumberg et al., 1967; Bank et al., 1971; Szumuness et al., 1973; Grossman et al., 1975; Mazzur and Jones, 1976; Papaevangelou et al., 1976; Sandler et al., 1977). Several surveys for HB antigen and antibody were conducted in Japan with sera prepared from blood for transfusion collected in the Japanese Red Cross Centers or hospitals. Such serum samples did not represent all age groups or localities and there has been a question as to whether those results reflect the general trend in Japan. This report deals with the prevalence of hepatitis B surface antigen ( $\mathrm{HBsAg}$ ) and antibody (HBsAb) among apparently healthy normal populations in Japan. The serum samples included all age groups and localities.

Serum samples were randomly selected from the collection of the National Serum Bank, National Institute of Health of Japan and consisted of those from 923 urban and 976 rural inhabitants of the ages ranging from zero to 98 years. The serum samples collected in 1972 were stored at $-70 \mathrm{C}$. They were heated at $56 \mathrm{C}$ for $30 \mathrm{~min}$ before use.

The serum samples were screened for HBsAg by reversed passive hemagglutination (R-PHA) and positive results were confirmed for specificity by the

湯浅田鶴子・多ケ谷 勇 (国立予防衛生研究所 腸内ウイルス部)

関根暉樹（国立肪んセンター 中央区築地 5 丁目)

西岡久寿弥 (東京都臨床医学総合研究所 文京区本駒込 3-18-22) 
TABLE I

Incidence of hepatitis $B$ antigen $(H B s A g)^{*}$ by age and sex in urban areas in Japan

\begin{tabular}{|c|c|c|c|c|c|c|c|c|c|}
\hline \multirow{3}{*}{$\begin{array}{c}\text { Age } \\
\text { (Year) }\end{array}$} & \multicolumn{3}{|c|}{ Male } & \multicolumn{3}{|c|}{ Female } & \multicolumn{3}{|c|}{ Total } \\
\hline & \multirow{2}{*}{$\begin{array}{c}\text { Number } \\
\text { tested }\end{array}$} & \multicolumn{2}{|c|}{ positives } & \multirow{2}{*}{$\begin{array}{c}\text { Number } \\
\text { tested }\end{array}$} & \multicolumn{2}{|c|}{ positives } & \multirow{2}{*}{$\begin{array}{c}\text { Number } \\
\text { tested }\end{array}$} & \multicolumn{2}{|c|}{ positives } \\
\hline & & Number & $\%$ & & Number & $\%$ & & Number & $\%$ \\
\hline $0-4$ & 28 & 0 & 0 & 30 & 0 & 0 & 58 & 0 & 0 \\
\hline $5-9$ & 50 & 2 & 4 & 51 & 1 & 2 & 101 & 3 & 3 \\
\hline $10-14$ & 50 & 1 & 2 & 50 & 0 & 0 & 100 & 1 & 1 \\
\hline $15-19$ & 50 & 0 & 0 & 50 & 1 & 2 & 100 & 1 & 1 \\
\hline $20-24$ & 46 & 2 & 4.4 & 50 & 2 & 4 & 96 & 4 & 4.2 \\
\hline $25-29$ & 45 & 1 & 2.2 & 50 & 0 & 0 & 95 & 1 & 1.1 \\
\hline $30-39$ & 50 & 0 & 0 & 52 & 1 & 1.9 & 102 & 1 & 1 \\
\hline $40-49$ & 47 & 0 & 0 & 50 & 0 & 0 & 97 & 0 & 0 \\
\hline $50-69$ & 50 & 1 & 2 & 50 & 0 & 0 & 100 & 1 & 1 \\
\hline 70-98 & 35 & 0 & 0 & 39 & 0 & 0 & 74 & 0 & 0 \\
\hline Total & 451 & 7 & 1.6 & 472 & 5 & 1.1 & 923 & 12 & 1.3 \\
\hline
\end{tabular}

* Titers of 1:4 or higher in reversed passive hemagglutination were taken as positive.

TABLE II

Incidence of hepatitis $B$ antigen ( $H B s A g)$ by age and sex in rural areas in Japan

\begin{tabular}{|c|c|c|c|c|c|c|c|c|c|}
\hline \multirow{3}{*}{$\begin{array}{c}\text { Age } \\
\text { (Year) }\end{array}$} & \multicolumn{3}{|c|}{ Male } & \multicolumn{3}{|c|}{ Female } & \multicolumn{3}{|c|}{ Total } \\
\hline & \multirow{2}{*}{$\begin{array}{c}\text { Number } \\
\text { tested }\end{array}$} & \multicolumn{2}{|c|}{ positives } & \multirow{2}{*}{$\begin{array}{c}\text { Number } \\
\text { tested }\end{array}$} & \multicolumn{2}{|c|}{ positives } & \multirow{2}{*}{$\begin{array}{c}\text { Number } \\
\text { tested }\end{array}$} & \multicolumn{2}{|c|}{ positives } \\
\hline & & Number & $\%$ & & Number & $\%$ & & Number & $\%$ \\
\hline $0-4$ & 50 & 0 & 0 & 37 & 0 & 0 & 87 & 0 & 0 \\
\hline $5-9$ & 50 & 1 & 2 & 49 & 1 & 2 & 99 & 2 & 2 \\
\hline $10-14$ & 49 & 3 & 6.1 & 50 & 3 & 6 & 99 & 6 & 6.1 \\
\hline $15-19$ & 50 & 5 & 10 & 49 & 3 & 6.1 & 99 & 8 & 8.1 \\
\hline $20-24$ & 40 & 0 & 0 & 50 & 2 & 4 & 90 & 2 & 2.2 \\
\hline $25-29$ & 37 & 2 & 5.4 & 50 & 0 & 0 & 87 & 2 & 2.3 \\
\hline $30-39$ & 54 & 0 & 0 & 45 & 1 & 2.2 & 99 & 1 & 1 \\
\hline $40-49$ & 52 & 2 & 3.8 & 50 & 2 & 4 & 102 & 4 & 3.9 \\
\hline $50-69$ & 51 & 1 & 2 & 50 & 1 & 2 & 101 & 2 & 2 \\
\hline $70-98$ & 55 & 1 & 1.8 & 58 & 1 & 1.7 & 113 & 2 & 1.8 \\
\hline Total & 488 & 15 & 3.1 & 488 & 14 & 2.9 & 976 & 29 & 3 \\
\hline
\end{tabular}

hemagglutination inhibition test (HAI) (Sekine, 1975). The serum samples showing fourfold or greater reduction in titer in the antibody-inhibited reaction were interpreted as positive. Subtype specificity was determined by HAI (Imai et al., 1974). Monospecific antibody to the a, $d, w$ or $r$ subtype determinant at 2 or 4 units was used. The serum samples were tested also by discontinuous counterimmunoelectrophoresis for HBsAg (Wallis and Melnick, 1971) in which the WHO reference antiserum (caprine WHO-S) and a serum from a hepatitis 
patient (SS-2) were used at dilutions of 1:20 and 1:5, respectively.

The HBsAb in the serum samples were detected by PHA using sheep erythrocytes coated with purified antigens and positive results were confirmed for specificity by the HAI test. The serum samples showing fourfold or greater reduction in titer in the antigen-inhibited reaction were interpreted as positive.

The HBsAg prevalence by age and sex among urban and rural healthy populations in Japan is shown in Tables I and II. In both rural and urban areas, Ag positives were first observed in the age group of 5 to 9 . In Japan, the rate of the transmission of $\mathrm{HB}$ virus from mothers to their infants was reported to be about $1 \%$ (Okada, 1975). The absence of HBsAg positives in 145 individuals of the age group of 0 to 4 years in the present study is compatible with the results of his report.

In urban areas, $\mathrm{Ag}$ positives were found in all age groups at $1 \%$ to $4.2 \%$ except two age groups of 40 to 49 and 70 to 98 , which lacked $\mathrm{Ag}$ positives. There was no significant difference between any two contiguous age groups $(\mathrm{p}>0.05)$. In rural areas, $6.1,8.1$ and $3.9 \%$ were $\mathrm{HBsAg}$ positives at the age groups of 10 to 14,15 to 19 and 40 to 49 , respectively. The rate of $\mathrm{HBsAg}$ positives in these three groups were significantly higher than those in other age groups $(\mathrm{p}<0.05)$.

The HBsAg prevalence among populations under 24 years of age was apparently higher than that among older populations in both areas $(2.0 \%$ vs $0.6 \%$ in urban and $3.8 \%$ vs $2.2 \%$ in rural area), but the difference was significant only when the data from both areas were combined and analyzed $(2.9 \%$ vs

\section{TABLE III}

HBs antigen determined by reversed passive hemagglutination and discontinuous counterimmunoelectrophoresis in sera from urban healthy populations

\begin{tabular}{|c|c|c|c|c|c|c|c|}
\hline & \multirow{2}{*}{ Sample } & \multirow{2}{*}{$\underset{\text { (Year) }}{\text { Age }}$} & \multirow{2}{*}{ Sex } & \multicolumn{2}{|c|}{ Reversed-PHA } & \multicolumn{2}{|c|}{ D-CIE against } \\
\hline & & & & Titer* & Subtype & SS-2** & WHO-S*** \\
\hline 1 . & 020073 (Aomori) & 8 & F. & 12.6 & adw & + & + \\
\hline 2. & 010122 (Hokkaido) & 9 & M. & 6.0 & $a d w$ & - & - \\
\hline 3. & 040512 (Miyagi) & 9 & M. & 11.6 & $\mathrm{adr}$ & + & + \\
\hline 4. & 010180 (Hokkaido) & 14 & M. & 12.6 & $a d w$ & + & + \\
\hline 5. & 440208 (Ooita) & 17 & F. & 10.6 & $\operatorname{adr}$ & + & + \\
\hline 6. & 240417 (Mie) & 20 & M. & 12.6 & adr & + & + \\
\hline 7. & C-1294 (Chiba) & 21 & M. & 13.6 & adr & + & + \\
\hline 8. & 430302 (Kumamoto) & 22 & F. & 4.0 & $\mathrm{adr}$ & - & - \\
\hline 9. & 150095 (Niigata) & 22 & F. & 6.0 & adw & - & - \\
\hline 10. & C-1272 (Chiba) & 25 & M. & 9.6 & adr & + & + \\
\hline 11. & 020163 (Aomori) & 32 & F. & 10.6 & adw & + & + \\
\hline 12. & 040792 (Miyagi) & 64 & M. & 5.0 & $a d w$ & - & - \\
\hline
\end{tabular}

* $\times(\log 2)^{-1}$

** Serum from a hepatitis patient $1: 5$.

*** WHO reference serum 1: 20 . 
TABLE IV

HBs antigen determined by reversed passive hemagglutination and discontinuous counterimmunoelectrophoresis in sera from rural healthy populations

\begin{tabular}{|c|c|c|c|c|c|c|c|}
\hline & \multirow{2}{*}{ Sample } & \multirow{2}{*}{$\begin{array}{c}\text { Age } \\
\text { (Year) }\end{array}$} & \multirow{2}{*}{ Sex } & \multicolumn{2}{|c|}{ Reversed-PHA } & \multirow{2}{*}{$\begin{array}{l}\text { D-CIE } \\
\text { SS-2 }\end{array}$} & \multirow{2}{*}{$\frac{\text { against }}{\text { WHO-S }}$} \\
\hline & & & & Titer & Subtype & & \\
\hline 13. & 420071 (Nagasaki) & 8 & F. & 11.6 & adr & + & + \\
\hline 14. & 010043 (Hokkaido) & 9 & M. & 12.6 & adr & + & + \\
\hline 15. & 010052 (Hokkaido) & 10 & M. & 11.6 & adw & + & + \\
\hline 16. & 010047 (Hokkaido) & 10 & F. & 5.0 & adw & ND* & ND \\
\hline 17. & 150685 (Niigata) & 11 & F. & 9.6 & adr & + & + \\
\hline 18. & 350150 (Yamaguchi) & 12 & F. & 13.6 & $a d r$ & + & + \\
\hline 19. & 420033 (Nagasaki) & 13 & M. & 11.6 & adr & + & + \\
\hline 20. & 380354 (Ehime) & 14 & M. & 12.6 & adw & + & + \\
\hline 21. & 340040 (Hiroshima) & 15 & M. & 12.6 & adr & + & + \\
\hline 22. & 340066 (Hiroshima) & 15 & M. & 12.6 & $\mathbf{a d r}$ & + & + \\
\hline 23. & 340082 (Hiroshima) & 15 & F. & 11.6 & $\mathrm{adr}$ & + & + \\
\hline 24. & 150478 (Niigata) & 17 & M. & 10.6 & adw & + & + \\
\hline 25. & 250028 (Shiga) & 17 & $\mathbf{F}$. & 11.6 & adw & + & + \\
\hline 26. & 420073 (Nagasaki) & 18 & F. & 7.0 & adw & - & - \\
\hline 27. & 100094 (Gumma) & 19 & M. & 11.6 & $\mathbf{a d r}$ & + & + \\
\hline 28. & 380374 (Ehime) & 19 & M. & 11.6 & adr & + & + \\
\hline 29. & 040143 (Miyagi) & 22 & F. & 2.0 & unidentified & - & - \\
\hline 30. & 390100 (Koochi) & 23 & F. & 9.6 & $\mathrm{adr}$ & + & - \\
\hline 31. & S-349 (Saitama) & 29 & M. & 4.0 & unidentified & - & - \\
\hline 32. & 350185 (Yamaguchi) & 29 & M. & 9.6 & adw & + & + \\
\hline 33. & 150492 (Niigata) & 39 & F. & 8.6 & $\mathrm{adr}$ & $\mathrm{ND}$ & + \\
\hline 34. & 380396 (Ehime) & 40 & F. & 3.0 & adr & - & - \\
\hline 35. & 150572 (Niigata) & 45 & M. & 6.0 & adw & - & - \\
\hline 36. & 150543 (Niigata) & 47 & F. & 7.0 & $\operatorname{adr}$ & + & + \\
\hline 37. & 100216 (Gumma) & 48 & M. & 7.0 & adw & + & - \\
\hline 38. & 150555 (Niigata) & 53 & M. & 7.0 & ND & - & - \\
\hline 39. & 150549 (Niigata) & 56 & $\mathbf{F}$. & 4.0 & adw & - & - \\
\hline 40. & 420138 (Nagasaki) & 91 & M. & 4.0 & unidentified & - & - \\
\hline 41. & 100806 (Gumma) & 95 & F. & 7.0 & $a d w$ & ND & ND \\
\hline
\end{tabular}

* ND: not done.

$1.4 \%, \mathrm{p}<0.05)$. Our results provide only cross-sectional data with HBsAg prevalence, including asymptomatic carriers and abortive infections which temporarily possess $\mathrm{HB}$ virus.

The carrier rate appears to be higher in tropical than in temperate settings, and higher in urban than in rural communities. The prevalence of both HB antigen and antibody is high among populations living under overcrowded or unhygienic conditions (WHO, 1975). In the present report, the overall $\mathrm{HBsAg}$ prevalence rate among urban healthy population was $1.3 \%$ and that among rural healthy population was $3.0 \%$. The latter was significantly higher than the former $(p<0.02)$, with no significant difference between males and females in 
both areas $(\mathrm{p}>0.5, \mathrm{p}>0.5)$. The overall prevalence rate in Japan was $2.2 \%$ $(41 / 1899)$, the value being similar to that $(2.7 \%)$ reported previously $(295 / 10738$, Nishioka et al., 1975).

The HBsAg titers of positive sera were determined by R-PHA. The reference sample containing one $\mu \mathrm{g}$ per $\mathrm{ml}$ of adr antigen showed $64\left(2^{6}\right) \mathrm{HA}$ units under our experimental conditions. Discontinuous counterimmunoelectrophoresis (D-CIE) was performed in parallel against anti-HB reference sera. The results are summarized in Tables III and IV. All the samples having less than $64\left(2^{6}\right)$ HA units were negative in D-CIE tests. Two of our samples containing $128\left(2^{7}\right)$ HA units in R-PHA were negative and one of them was positive only against SS-2. Therefore, the sensitivity of D-CIE was about one-hundredth that of R-PHA in detecting HBsAg. The HBsAg titers in relation to the ages are also summarized in Tables III and IV. The mean titers of HBsAg positives were $2050\left(2^{11}\right), 294\left(2^{8.2}\right)$ and $49\left(2^{5.6}\right)$ HA units in age groups of 5-19, 20-39 and $>40$ years, respectively. The difference was significant among these three groups $(\mathrm{t}<0.01, \mathrm{t}<0.05)$, indicating age-dependent decrease in $\mathrm{HBsAg}$ titer in the serum of adults older than 20 years.

Subtypes of HBsAg were identified in 37 of 41 samples, 20 as adr (54.1\%) and the other 17 as adw (45.9\%). Since the discovery of $\mathrm{d}, \mathrm{y}, \mathrm{w}$ and $\mathrm{r}$ subtype determinants of HBsAg (LeBouvier, 1971; Bancroft et al., 1972), data on peculiar geographic distribution of each determinant have been accumulated (Mazzur et al., 1973; Feinman et al., 1973; Dodd et al., 1973). Data in Tables III and IV also reveal the geographic distribution of each subtype in Japan. The south-to-north descending gradient in distribution of the $r$ determinant in Japan is evident from the tables and this is in general agreement with the data obtained by other researchers (Ishida et al., 1973; Mazzur et al., 1974; Yamashita et al., 1975) except that the frequency of $r$ determinant was lowest in Hokkaido in our study but it was higher than that in the northern part of Honshu Island in their studies.

The HBsAb distribution by age and sex among urban and rural populations is shown in Tables V and VI. A few HBsAb positives were found in the youngest age group in both areas. In urban areas, $\mathrm{HBsAb}$ prevalence increased with age up to 40 years and then decreased, but in rural areas, it appeared to reach a plateau at the age of 20 years. The overall positive rate of $\mathrm{HBsAb}$ was nearly the same in both areas $(16.5 \%$ in urban and $16.3 \%$ in rural areas), but it was significantly higher in females than in males $(p<0.01)$, mainly due to the significant difference in urban areas $(\mathrm{p}<0.02)$. An increase in the prevalence of HBsAb with age was shown in the present study, as had been established by previous serosurveys.

The HBsAb prevalence rate in Japan is $16.4 \%$ (311/1899), the rate being similar to that $(18.4 \%, 1949 / 10567)$ obtained by Nishioka et al. (1975).

The HBsAb titers of positive sera were determined by PHA. The results are shown in Fig. 1. Although in the urban area, there was no significant difference in average $\mathrm{Ab}$ titers between every two contiguous age groups, in 
TABLE V

Incidence of $H B$ s antibody (HBsAb) by age and sex in urban areas in Japan

\begin{tabular}{|c|c|c|c|c|c|c|c|c|c|}
\hline \multirow{3}{*}{$\begin{array}{c}\text { Age } \\
\text { (Year) }\end{array}$} & \multicolumn{3}{|c|}{ Male } & \multicolumn{3}{|c|}{ Female } & \multicolumn{3}{|c|}{ Total } \\
\hline & \multirow{2}{*}{$\begin{array}{c}\text { Number } \\
\text { tested }\end{array}$} & \multicolumn{2}{|c|}{ Positives } & \multirow{2}{*}{$\begin{array}{c}\text { Number } \\
\text { tested }\end{array}$} & \multicolumn{2}{|c|}{ Positives } & \multirow{2}{*}{$\underset{\text { tested }}{\text { Number }}$} & \multicolumn{2}{|c|}{ Positives } \\
\hline & & Number & $\%$ & & Number & $\%$ & & Number & $\%$ \\
\hline $0-4$ & 28 & 1 & 3.6 & 30 & 1 & 3.3 & 58 & 2 & 3.4 \\
\hline $5-9$ & 50 & 0 & 0 & 51 & 3 & 5.9 & 101 & 3 & 3 \\
\hline $10-14$ & 50 & 1 & 2 & 50 & 6 & 12 & 100 & 7 & 7 \\
\hline $15-19$ & 50 & 7 & 14 & 50 & 5 & 10 & 100 & 12 & 12 \\
\hline $20-24$ & 46 & 2 & 4.3 & 50 & 7 & 14 & 96 & 9 & 9.4 \\
\hline $25-29$ & 45 & 5 & 11.1 & 50 & 10 & 20 & 95 & 15 & 15.8 \\
\hline $30-39$ & 50 & 15 & 30 & 52 & 12 & 23.1 & 102 & 27 & 26.5 \\
\hline $40-49$ & 47 & 14 & 29.8 & 50 & 17 & 34 & 97 & 31 & 32 \\
\hline $50-69$ & 50 & 11 & 22 & 50 & 16 & 32 & 100 & 27 & 27 \\
\hline $70-98$ & 35 & 6 & 17.1 & 39 & 13 & 33.3 & 74 & 19 & 25.7 \\
\hline Total & 451 & 62 & 13.7 & 472 & 90 & 19.1 & 923 & 152 & 16.5 \\
\hline
\end{tabular}

TABLE VI

Incidence of HBs antibody (HBsAb) by age and sex in rural areas in Japan

\begin{tabular}{|c|c|c|c|c|c|c|c|c|c|}
\hline \multirow{3}{*}{$\begin{array}{c}\text { Age } \\
\text { (Year) }\end{array}$} & \multicolumn{3}{|c|}{ Male } & \multicolumn{3}{|c|}{ Female } & \multicolumn{3}{|c|}{ Total } \\
\hline & \multirow{2}{*}{$\begin{array}{c}\text { Number } \\
\text { tested }\end{array}$} & \multicolumn{2}{|c|}{ Positives } & \multirow{2}{*}{$\begin{array}{c}\text { Number } \\
\text { tested }\end{array}$} & \multicolumn{2}{|c|}{ Positives } & \multirow{2}{*}{$\begin{array}{c}\text { Number } \\
\text { tested }\end{array}$} & \multicolumn{2}{|c|}{ Positives } \\
\hline & & Number & $\%$ & & Number & $\%$ & & Number & $\%$ \\
\hline $0-4$ & 50 & 1 & 2 & 37 & 0 & 0 & 87 & 1 & 1.1 \\
\hline $5-9$ & 50 & 1 & 2 & 49 & 4 & 8.2 & 99 & 5 & 5.1 \\
\hline $10-14$ & 49 & 4 & 8.2 & 50 & 8 & 16 & 99 & 12 & 12.1 \\
\hline $15-19$ & 50 & 7 & 14 & 49 & 8 & 16.3 & 99 & 15 & 15.2 \\
\hline $20-24$ & 40 & 9 & 22.5 & 50 & 9 & 8 & 90 & 18 & 20 \\
\hline $25-29$ & 37 & 7 & 18.9 & 50 & 8 & 16 & 87 & 15 & 17.2 \\
\hline $30-39$ & 54 & 11 & 20.4 & 45 & 9 & 20 & 99 & 20 & 20.2 \\
\hline $40-49$ & 52 & 7 & 13.5 & 50 & 13 & 26 & 102 & 20 & 19.6 \\
\hline $50-69$ & 51 & 13 & 25.5 & 50 & 10 & 20 & 101 & 23 & 22.8 \\
\hline $70-98$ & 55 & 11 & 20 & 58 & 19 & 32.8 & 113 & 30 & 26.5 \\
\hline Total & 488 & 71 & 14.5 & 488 & 88 & 18.0 & 976 & 159 & 16.3 \\
\hline
\end{tabular}

rural the antibody titer was significantly higher at age 5 to $19(\mathrm{~F}>0.05, \mathrm{~F}<0.01)$ than that in other age groups.

From our data, the overall average rate of minimum estimate of prior infection in Japan must be $18.5 \%$ (Fig. 2). In urban areas, the rate of minimum estimate reached the average at ages of 30 to $39(30 \%)$ in males and 20 to $24(18 \%)$ in females. On the other hand, in rural areas it reached the average at ages of 15 to $19(24 \%)$ in males and 10 to $14(22 \%)$ in females.

In the present study the ratio of the $\mathrm{HBsAb}$ frequency to the $\mathrm{HBsAg}$ 

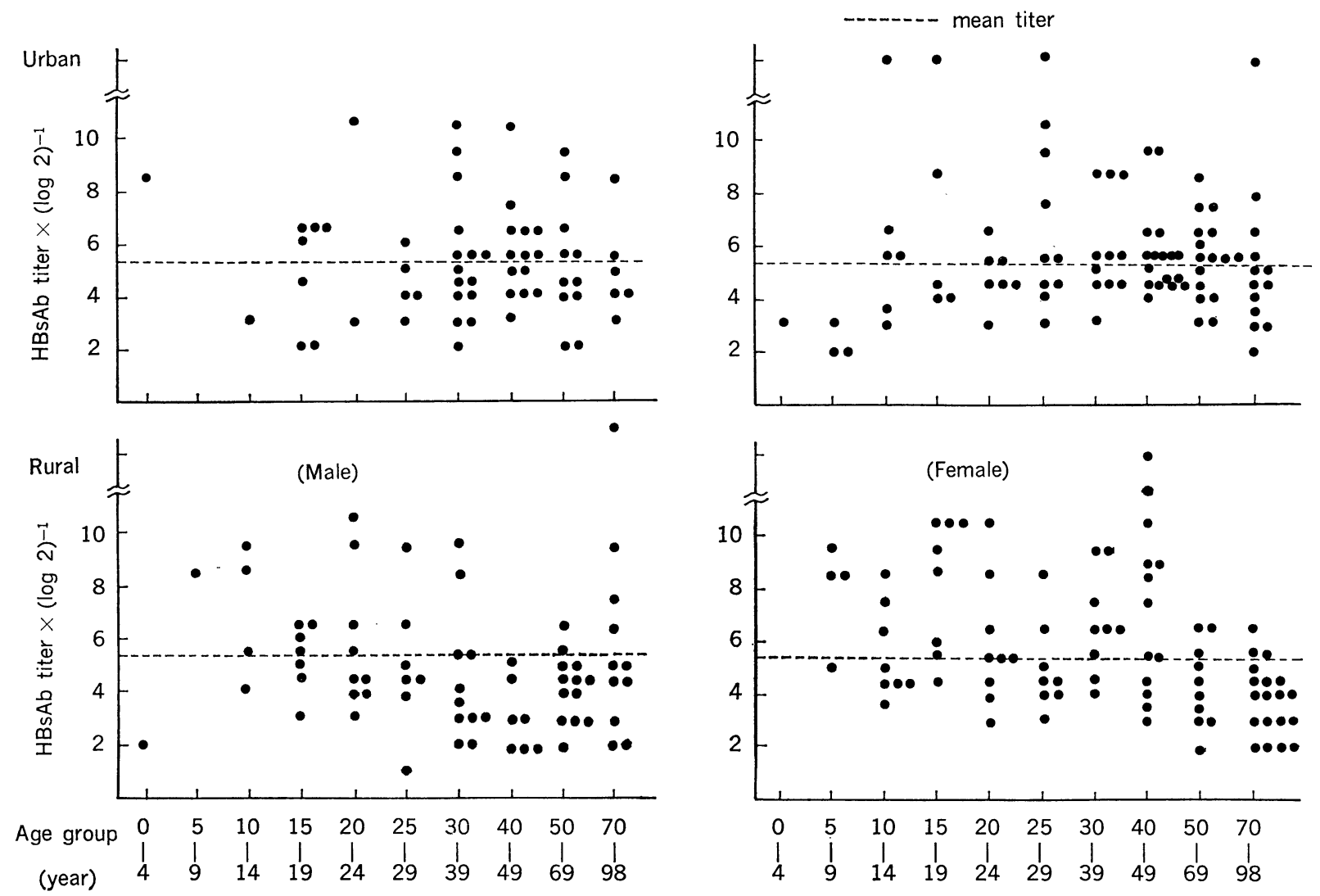

Fig. 1. Titration for HBs antibody of sera of healthy population in Japan. 

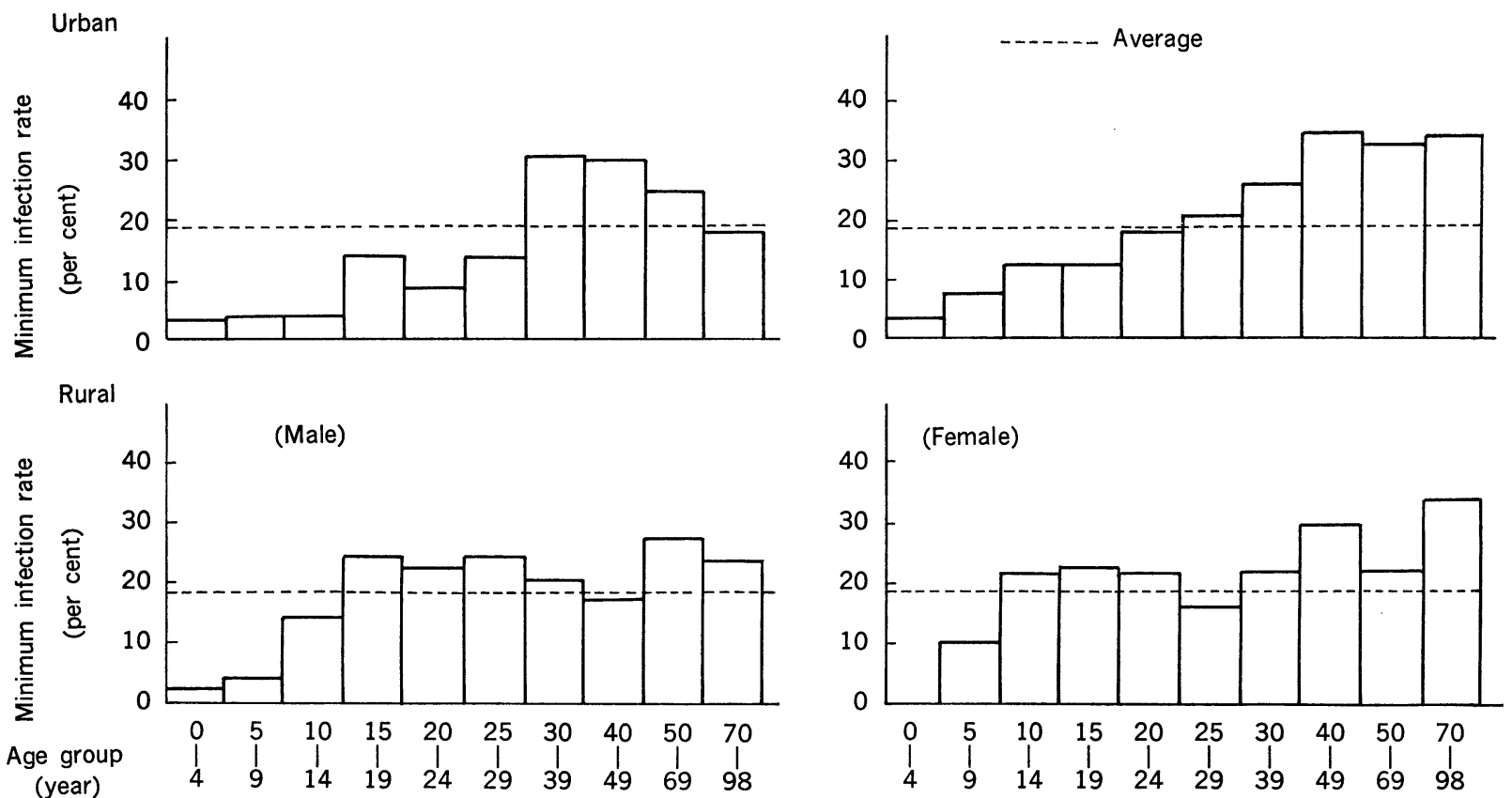

Fig. 2. Minimum estimate of prior infection with hepatitis $B$ virus among healthy Japanese. 
frequency in inhabitants in urban areas is significantly higher than that in rural areas, without sex difference. This indicates that in rural areas there are more HBsAg positives especially among those younger than 20 years, who will often become chronic carriers.

\section{ACKNOWLEDGEMENT}

We are grateful to Dr. H. Shimojo and Dr. Y. Tsuchiya, Department of Enteroviruses, National Institute of Health, for their helpful advice.

We are also grateful to the members of the National Serum Bank, National Institute of Health of Japan for supplying us with serum samples.

\section{REFERENCES}

Banke, O., Dybkjaer, E., Nordenfelt, E. And Reinicke, V. (1971): Australia antigen antibody in 10,000 Danish blood-donors. Lancet, $i, 860-861$.

Bancroft, W. H., Mundon, F. K. and Russell, P. K. (1972): Detection of additional antigenic determinants of hepatitis $\mathbf{B}$ antigen. J. Immunol., 109, 842-848.

Blumberg, B. S., Melartin, L., Lechat, M. and Guinto, R. S. (1967): Association between lepromatous leprosy and Australia antigen. Lancet, $i$, 173-176.

Dodd, R. Y., Holland, P. V., Ni, L. Y., Smith, H. M. and Greenwalt, T. J. (1973): Hepatitis B antigen: regional variation in incidence and subtype ratio in the American Red Cross blood donor population. Amer. J. Epidemiol., 97, 111-115.

Feinman, S. V., Berris, B., Sinclair, J. G., Wrobel, D. M., Alter, H. J. and Holland, P. V. (1973): Relation of hepatitis-B-antigen subtypes in symptom-free carriers to geographical origin and liver abnormalties. Lancet, $i i, 867-869$.

Grossman, R. A., Benenson, N. W., Scott, R. M., Snitbhan, R., Top, F. H. and Pantuwatana, S. (1975): An epidemiological study of hepatitis B virus in Bangkok, Thailand. Amer. J. Epidemiol., 101, 144-159.

Imai, M., Yamashita, Y., Miyakawa, Y. AND Mayumi, M. (1974): Haemagglutination inhibition assay of the common determinants and subspecificities of Australia antigen. Immunology, $27,871-878$.

Ishida, N., Umenai, T., O'Connell, A. ANd Mrllman, I. (1973): HBAg subtypes in Japan. Lancet, $i i, 498-499$.

Lebouvier, G. L. (1971): The heterogeneity of Australia antigen. J. Infect. Dis., 123, 671-675.

Mazzur, S., Falker, D. and Blumberg, B. S. (1973): Geographical variation of "w" subtype of Australia antigen. Nature New Biol., 243, 44-47.

Mazzur, S., Burgert, S. ANd Blumberg, B. S. (1974): Geographical distribution of Australia antigen determinants $\mathrm{d}, \mathrm{y}$ and $\mathrm{w}$. Nature, 247, 38-40.

Mazzur, S. ANd Jones, N. (1976): Equal susceptibility of males and females on Santa Cruz Island to the carrier state of hepatitis B surface antigen. J. Infect. Dis., 133, 331-333.

NishiokA, K., Levin, A. G. ANd Simon, M. J. (1975): Hepatitis B antigen, antigen subtypes, and normal subjects and patients with liver disease. Results of a collaborative study. Bull. WHO, 52, 293-300.

OKADA, K. (1975): Establishment of HB virus carrier; vertical transmission. Clinician, 22, 4346 (text in Japanese).

Oкосні, K. AND Murakami, S. (1968): Observation on Australia antigen in Japanese. Vox Snag., $15,374-385$.

Papaevangelou, G., Kyriakidou, A., Vissoulis, G. and Trichopoulos, D. (1976): Seroepidemiological study of HBV infections in Athens, Greece. J. Hyg., 76, 229-234.

SANDler, S. G., NATH, N. AND Biger, Y. (1977): Seroepidemiology of Hepatitis B virus in Israel. Amer. J. Epidemiol., 106, 76-82.

Sekine, T. (1975): HB antigen detection by reversed passive agglutination. Japan. J. Clin. Pathol., 23, 665-668 (text in Japanese). 
Szmuness, W., Prince, A. M., Diebolt, G., Leblanc, L., Baylet, R., Masseyeff, R. And Linhard, J. (1973): The epidemiology of hepatitis B infections in Africa: results of pilot survey in the Republic of Senegal. Amer. J. Epidemiol., 98, 104-110.

Wallis, C. AND Melnick, J. L. (1971): Enhanced detection in serum hepatitis by discontinuous counter-immunoelectrophoresis. Appl. Microbiol., 21, 867-869.

World Health Organization (1975): Viral hepatitis. WHO Techn. Rep. Ser., No. 570, p. 1-51.

Yamashita, Y., Kurashina, S., Miyakawa, Y. and Mayumi, M. (1975): South-to-north gradient in distribution of the $\mathbf{r}$ determinant of hepatitis B surface antigen in Japan. J. Infect. Dis., $131,567-569$. 